This is a post-peer-review, pre-copyedit version of an article published in Agroforestry Systems. The final authenticated version is available online at: http://dx.doi.org/10.1007/s10457-017-0132-3 


\section{Spatial similarities between European agroforestry systems and ecosystem services at the}

\section{landscape scale}

Sonja Kay ${ }^{1 *}$, Josep Crous-Duran ${ }^{2}$, Nuria Ferreiro-Domínguez ${ }^{2,3}$, Silvestre García de Jalón ${ }^{4}$, Anil Graves $^{4}$, Gerardo Moreno ${ }^{5}$, María Rosa Mosquera-Losada ${ }^{3}$, João H.N. Palma², José V. Roces-Díaz ${ }^{1}$, Jose Javier Santiago-Freijanes ${ }^{3}$, Erich Szerencsits ${ }^{1}$, Robert Weibel ${ }^{6}$ and Felix Herzog ${ }^{1}$

1. Agroscope, Department of Agroecology and Environment, Zurich, Switzerland

2. Forest Research Centre, School of Agriculture, University of Lisbon, Lisbon, Portugal

3. Department of Crop Production and Engineering Projects, Escuela Politécnica Superior, Universidad de Santiago de Compostela, 27002 Lugo, Spain

4. Cranfield University. Cranfield, Bedfordshire, MK43 0AL, United Kingdom

5. Forestry Research Group, Universidad de Extremadura, Spain

6. University of Zurich, Department of Geography, Zurich, Switzerland

\footnotetext{
* cooresponding author: Agroscope, Reckenholzstrasse 191, 8046 Zurich, Switzerland, Tel: 0041-584687290,
} sonja.kay@agroscope.admin.ch,

Abstract: Agroforestry systems are known to provide ecosystem services which differ in quantity and quality from conventional agricultural practices and could enhance rural landscapes. In this study we compared ecosystem services provision of agroforestry and nonagroforestry landscapes in case study regions from three European biogeographical regions: Mediterranean (montado and dehesa), Continental (orchards and wooded pasture) and Atlantic agroforesty systems (chestnut soutos and hedgerows systems). Seven ecosystem service indicators (two provisioning and five regulating services) were mapped, modelled and assessed.

Clear variations in amount and provision of ecosystem services were found between different types of agroforestry systems. Nonetheless regulating ecosystems services were improved in all agroforestry landscapes, with reduced nitrate losses, higher carbon sequestration, reduced soil losses, higher functional biodiversity focussed on pollination and greater habitat diversity reflected in a high proportion of semi-natural habitats. The results for provisioning services were inconsistent. While the annual biomass yield and the groundwater recharge rate tended to be higher in agricultural landscapes without agroforestry systems, the total biomass stock was reduced. These broad relationships were observed within and across the case study regions regardless of the agroforestry type or biogeographical region. Overall our study underlines the positive influence of agroforestry systems on the supply of regulating services and their role to enhance landscape structure.

Keywords: biodiversity, biomass production, carbon sequestration, erosion, groundwater recharge, nitrate leaching, pollination, 


\section{Introduction}

Around forty percent of the European land area is used for agriculture (Eurostat 2013). Farmers cultivate the land to ensure food, fodder, energy and material supply, and by doing so, they shape the rural landscape (van der Zanden et al. 2016). Structural changes in agriculture, due to mechanisation and intensification of production, are thus reflected as visible changes in the landscape. Larger fields and farms as well as the removal of landscape elements such as trees, hedgerows, or wet areas have been some of the consequences (Biasi et al. 2016), resulting in the loss of the associated functions and environmental problems such as water pollution, erosion, and biodiversity loss (Tilman 1999). Thus, the performance of agricultural land should not only be evaluated in relation to its production function but also in terms of demands for environmental, regulating, and aesthetic benefits from landscapes (Dale and Polasky 2007).

The Millennium Ecosystem Services Assessment outlined the value of ecosystems and their ecosystem services (ES) into provisioning, regulating and cultural services (MEA 2003; Haines-Young \& Potschin 2013) and showed how these were degrading on a global scale. Subsequently this has triggered increased efforts in measuring, quantifying and mapping ES (e.g. Maes et al. 2012a) along with assessments of synergies and trade-offs in ES (e.g. Turner et al. 2014; Mouchet et al. 2017) in order to maintain the functionality of ecosystems and their benefits to society.

Agroforestry which deliberately integrates woody elements like trees or shrubs with agricultural crops and/or livestock has been proposed as an alternative land use approach that could potentially enhance ES provision (Pimentel et al. 1992; Jose 2009). Agroforestry systems (AF) have been identified for their high nature value and biodiversity (McNeely and Schroth 2006; Oppermann et al. 2012) and are listed for this in the EU Habitats Directive, receiving protection under the NATURA 2000 network (European Commission 1992). Their positive impact on all three ES pillars (provisioning, regulating and cultural, e.g. Torralba et al. 2016) and biodiversity are well studied at a local scale in wooded pastures (Moreno et al. 2016) and fruit orchards (e.g. Bailey et al. 2010), but little research exists on the benefits of agroforestry systems at the panEuropean scale.

This paper therefore explores the potential of traditional temperate agroforestry systems to provide provisioning and regulating ES and investigates their spatial impact at the landscape scale. The cultural ES provision is presented by Fagerholm et al. (2016). We conducted case studies in three European biogeographical regions (Mediterranean, Continental and Atlantic). The study aimed to answer two specific research questions: (1) Do agroforestry practices enhance landscape in comparison to agricultural land by providing additional regulating ES? 
(2) Are these effects similar in different regions even though the specific types of agroforestry are different? In order to answer these two questions, we identified a set of case study areas in our selected biogeographical regions, modelled the provision of ES for each agroforestry system in those areas, and then aggregated the findings to make our assessment across all the case studies.

\section{Data and Methods}

Six traditional European agroforestry landscapes (extent $>50 \mathrm{~km}^{2}$ ) in Mediterranean, Continental, and Atlantic regions were selected. In each region, four to seven adjacent municipalities were chosen and land use was broadly classified into agriculture (nonagroforestry) and agroforestry based on regional land use classification. In each of these two categories, four landscape test sites (LTS) of $1 \mathrm{~km} \mathrm{x} 1 \mathrm{~km}$ each were selected randomly. A field protocol was used to map the habitats and the AF trees or AF hedgerows via a combination of aerial photograph interpretation and fieldwork in all LTS in a uniform manner. Field data were digitised and intersected with AF elements to generate habitat maps that allowed to undertake spatial ES assessment.

\subsection{Case study regions}

The selected case study regions with typical agroforestry systems were: (1) montado in Portugal, (2) dehesa in Spain, (3) cherry orchards and (4) wooded pastures in Switzerland, (5) chestnut soutos in Spain and (6) hedgerow agroforestry landscapes in the United Kingdom. The systems differ in character, management and objectives. Figure 1 shows the location of the regions, the composition and pictures of the LTS. 

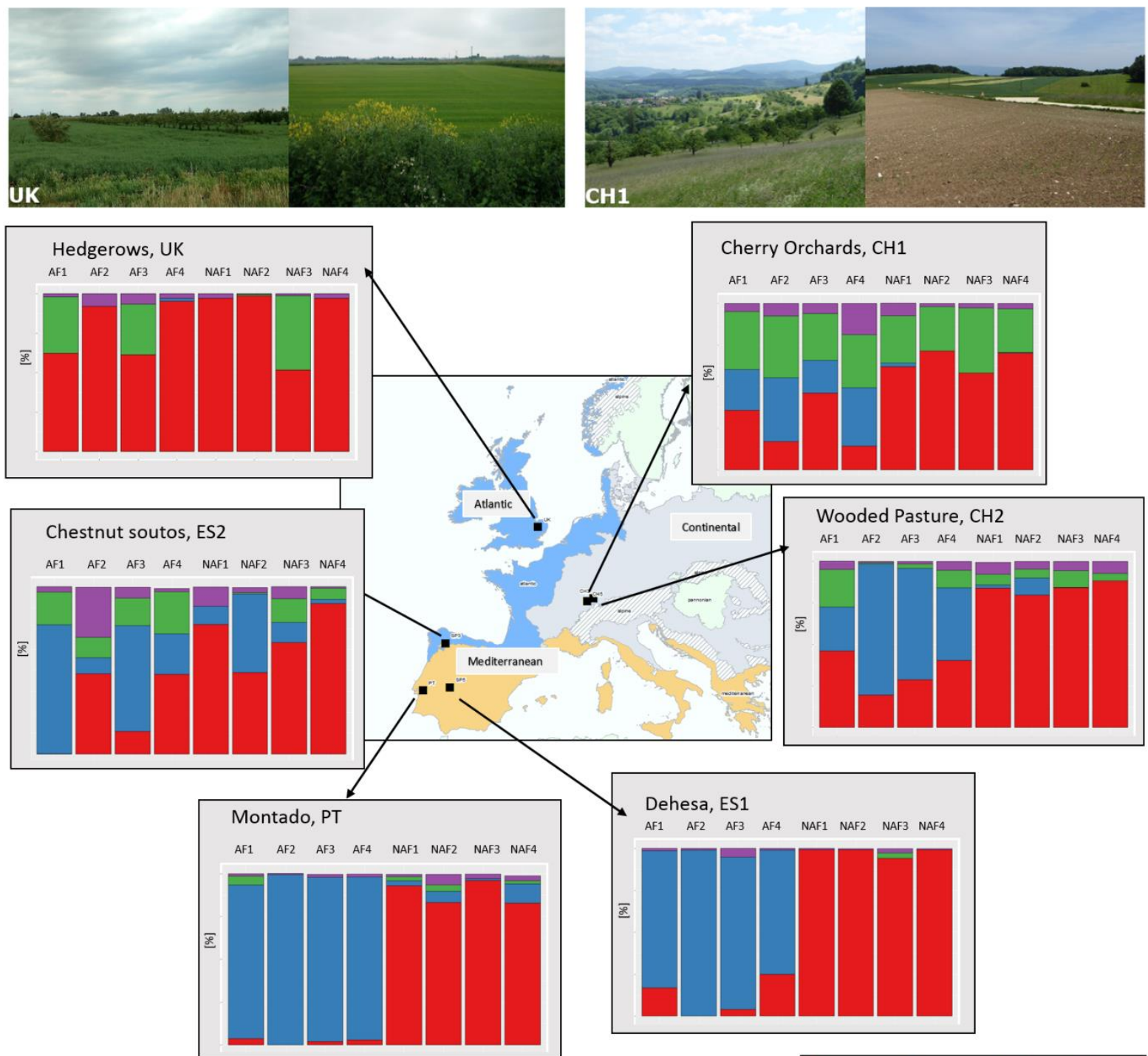

Cherry Orchards, $\mathrm{CH} 1$

AF1 AF2 AF3 $\quad$ AF4 NAF1 NAF2 NAF3 NAF4
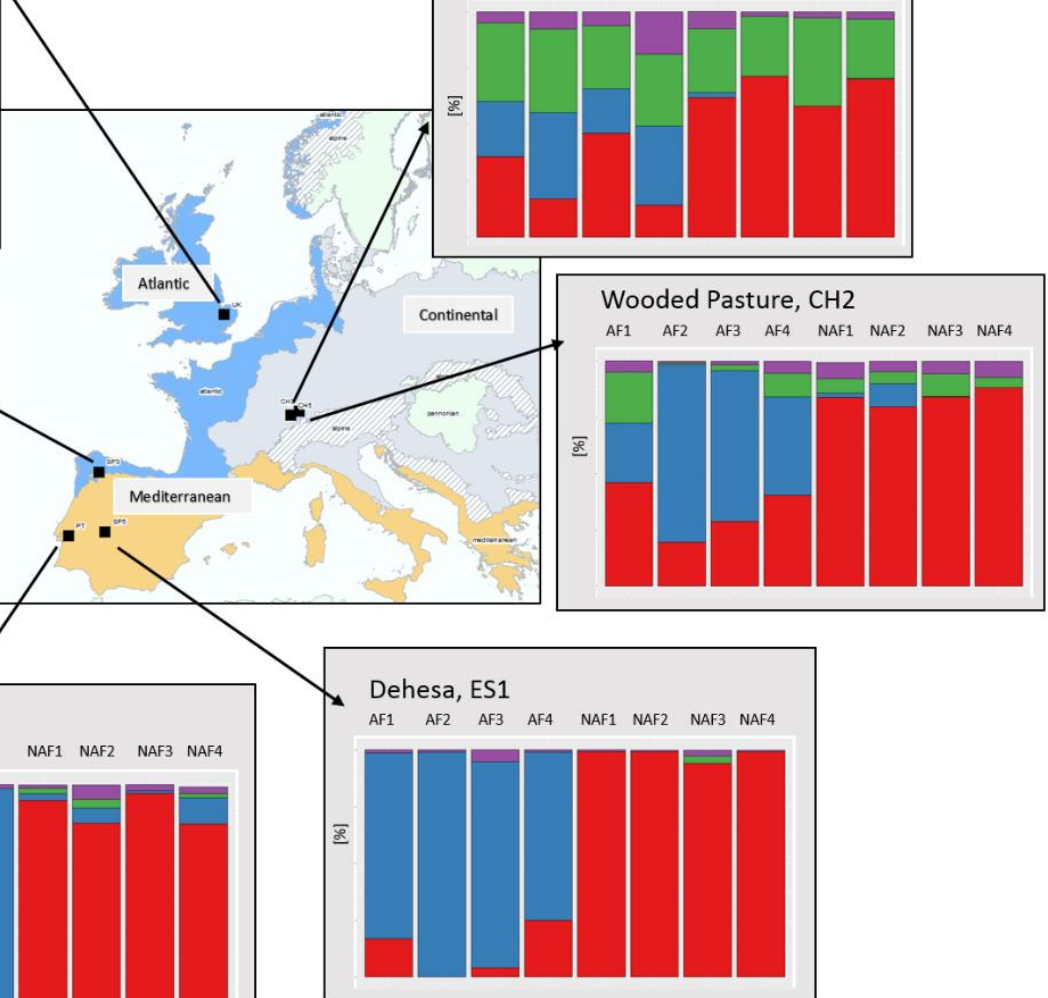

$\square$ Agriculture $\square$ Agroforestry $\square$ Forest $\square$ others
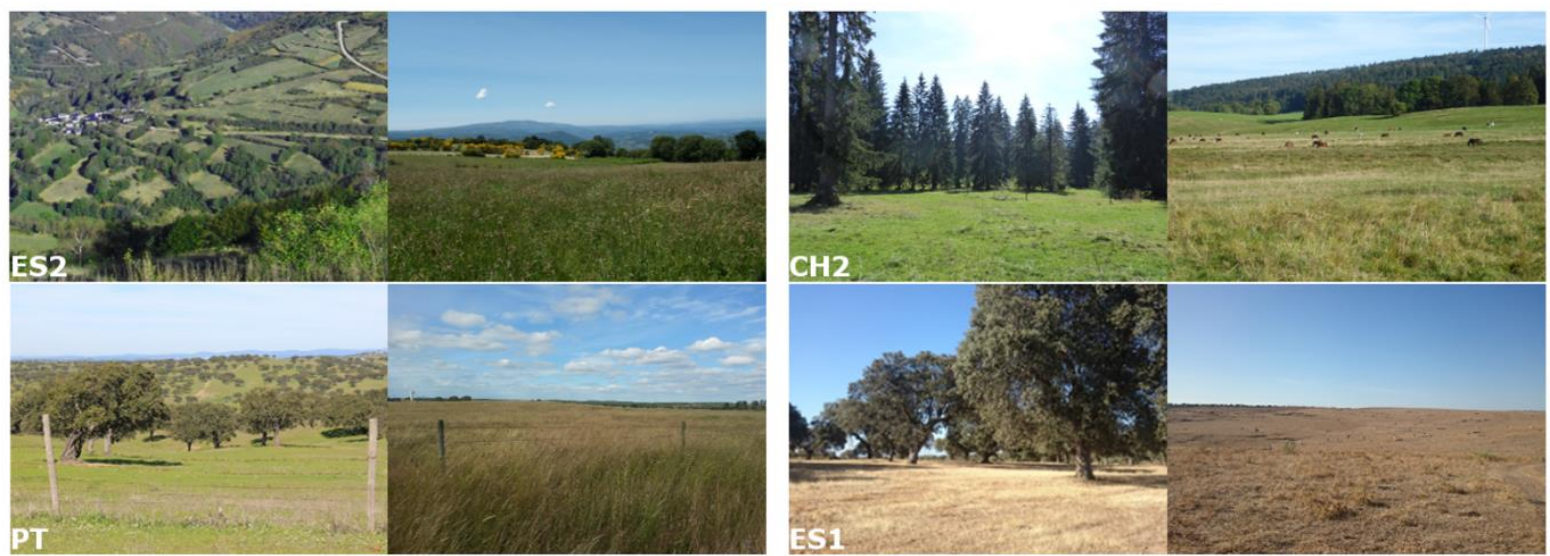

Figure 1: Location of the case study region, habitat composition and pictures of agroforestry (AF, left) and non-agroforestry (NAF, right) landscape test sites (LTS).

(1) Montados occupy an area of 736,775 hectares in Portugal (AFN 2010) and are characterized by low density trees $\left(25-50\right.$ trees $\left.\mathrm{ha}^{-1}\right)$ combined with agriculture or pastoral activities (Pereira 
and Tomé 2004). The main tree species are cork oak (Quercus suber L.) and/or holm oak (Quercus rotundifolia Lam.). Depending on the main tree species present, two different types of "montados" exist: 1) Cork oak montado where cork extraction is dominant, and 2) Holm oak montado where livestock (mainly cattle or sheep) are grazed during spring and Iberian pigs feed on acorns in autumn (Gaspar et al. 2007). The habitat mapping was done in Montemor-o-Novo, located in Central Portugal.

(2) Dehesas are very similar to holm oak montados, with Quercus ilex L. In Spain dehesas occupy around 3.5 million hectares of land (Plieninger et al. 2015) and has a random pattern of around 25 trees $\mathrm{ha}^{-1}$ where permanent grassland provides fodder in the form of acorns and grass for animal production. In addition to this, the timber and many other non-timber products are used (Fagerholm et al. 2016). The LTS selected for the ES assessment were located in Trujillo, in the southern Spanish region of Extremadura.

(3) The cherry (Prunus avium L.) orchards are located in the north-western part of Switzerland. Traditional fruit orchards are widespread in central Europe (approximately 1 million hectares, (Herzog 1998a)) and were mainly established for subsistence and commercial fruit production. The cherry orchards in the Cantons of Solothurn and Basel-Landschaft usually consist in 50 80 trees $\mathrm{ha}^{-1}$ of mixed age on permanent grassland that is grazed with cattle and occasionally mown.

(4) The spruce (Picea abies L.) dominated wooded pastures, are located in the Jura mountains in western Switzerland, covering about 50,000 hectares (Herzog 1998b). Wood pastures are common in mountain areas and typically consist of dense and sparse woodland in a mosaic pattern (Buttler et al. 2009). The trees produce timber and fodder, typically for free ranging cattle and horses. The case study site was located around Saignelégier in the Canton Jura.

(5) Chestnut (Castanea sativa Miller) soutos are a traditional land use system in north-western Iberia (Nati et al. 2016). They consist of ancient valuable trees (400 years old), are protected by the NATURA 2000 habitat network and occupy more than 350,000 hectares of land in Galicia and about 40,000 ha in Portugal. The system produces chestnut, fruit, and timber. In addition, it is known for mushroom production and in some areas grazed with pigs (Rigueiro-Rodríguez et al. 2014). The case study site was located in the western mountains of Lugo province in Galicia (Spain).

(6) The hedgerows landscape in eastern England covers around 551,000 hectares of land and is widely spread in the UK (den Herder et al. 2017). The case study region near Thetford, in the Breckland district of Norfolk, consists of cereal crops surrounded by hedgerows. These contain several species of broadleaf trees and shrubs that were traditionally used for firewood. In 
addition to their use for marking field boundaries (living fence), they are used as a wind-break to reduce soil erosion by wind.

\subsection{Indicator assessment}

For each LTS we evaluated seven ES indicators; namely biomass yield and groundwater recharge rate as provisioning ES and the regulating services nitrate leaching, carbon sequestration, soil erosion, and biodiversity divided into pollination and habitat richness. The selection follows the Common International Classification of Ecosystem Services (CICES) classification (Haines-Young and Potschin 2013) with focus on relevant indicators in agriculture and agroforestry systems. The indicators, methods and data sources are summarised in Table1.

Table 1: Ecosystem services indicators, methods and references.

\begin{tabular}{|c|c|c|c|c|c|}
\hline $\begin{array}{l}\text { CICES } \\
\text { Section - Division }\end{array}$ & & ES indicator & Model & Unit & References \\
\hline \multirow[t]{2}{*}{ Provisioning } & Material & Biomass yield & $\begin{array}{l}\text { EcoYield- } \\
\text { SAFE }\end{array}$ & $\begin{array}{l}\mathrm{t} \text { dry matter } \\
\mathrm{ha}^{-1} \mathrm{yr}^{-1} \\
\mathrm{t} \text { dry matter } \\
\mathrm{ha}^{-1}\end{array}$ & $\begin{array}{l}\text { Palma et al, } \\
\text { submitted.; van } \\
\text { der Werf et al. } \\
2007\end{array}$ \\
\hline & Water & $\begin{array}{l}\text { Groundwater } \\
\text { recharge rate }\end{array}$ & Water balance & $\mathrm{mm}$ & $\begin{array}{l}\text { Allen et al. 1998; } \\
\text { Hürdler et al. } \\
2015\end{array}$ \\
\hline \multirow{5}{*}{$\begin{array}{l}\text { Regulating and } \\
\text { maintenance }\end{array}$} & $\begin{array}{l}\text { Nutrient } \\
\text { retention }\end{array}$ & Nitrate leaching & $\begin{array}{l}\text { MODIFFUS } \\
3.0\end{array}$ & $\operatorname{kg~N~ha-1~} \mathrm{yr}^{-1}$ & $\begin{array}{l}\text { Hürdler et al. } \\
2015\end{array}$ \\
\hline & $\begin{array}{l}\text { Soil } \\
\text { preservation }\end{array}$ & Erosion & RUSLE & t soil ha ${ }^{-1} \mathrm{yr}^{-1}$ & $\begin{array}{l}\text { Renard et al. } \\
\text { 1997; Panagos et } \\
\text { al. } 2015\end{array}$ \\
\hline & $\begin{array}{l}\text { Climate } \\
\text { regulation }\end{array}$ & $\begin{array}{l}\text { Carbon } \\
\text { sequestration }\end{array}$ & $\begin{array}{l}\text { EcoYield- } \\
\text { SAFE, } \\
\text { Yasso07 }\end{array}$ & $\begin{array}{l}\text { t C ha-1 } \mathrm{yr}^{-1} \\
\text { t C ha- }\end{array}$ & $\begin{array}{l}\text { Liski et al. 2005; } \\
\text { Palma et al. } \\
\text { submitted }\end{array}$ \\
\hline & Pollination & Pollination & Lonsdorf & $\%$ & $\begin{array}{l}\text { Lonsdorf et al. } \\
2009\end{array}$ \\
\hline & $\begin{array}{l}\text { Gene pool } \\
\text { protection }\end{array}$ & Habitat richness & $\begin{array}{l}\text { SIDI, SoSNH, } \\
\text { HD }\end{array}$ & Unitless & $\begin{array}{l}\text { Bailey et al. } \\
\text { 2007; Billeter et } \\
\text { al. } 2008\end{array}$ \\
\hline
\end{tabular}

Indicators were calculated using spatial ES assessment models based on the habitat maps in combination with climate (online climate tool CliPic, (Palma 2017), soil (European Soil Database (ESDB)) and topographical information (International Centre for Tropical Agriculture (CIAT), digital elevation model (DEM) by Reuter et al. (2007) and Jarvis et al. (2008)) for each case study region. 
The estimations of AF trees biomass production, crop yields and carbon sequestered (divided into annual use e.g. cereals, fruits, prunings, timber and total stock) by the systems' above and below ground biomass were provided using the EcoYield-SAFE model, a process-based agroforestry growth model that was calibrated for the assessed systems (Palma et al., submitted). In the hedgerow agroforestry landscape in the UK, observed data from farms were utilised. The average yield for cropland production came from FAO (2017).

The groundwater recharge rate was assessed using the water balance equation, which links precipitation $(\mathrm{P})$, evapotranspiration $(\mathrm{E})$, surface runoff $(\mathrm{R})$ and the belowground water exchange $(\Delta S)$. The latter is the sum of storage change in the soil $\left(\Delta \mathrm{S}_{\text {Soil }}\right)$ and the ground water recharge $\left(\Delta \mathrm{S}_{\text {Groundwater recharge }}\right)$ (Equations 1,2$)$.

$P=E+R+\Delta S \quad$ with $\Delta S=\left(\Delta S_{\text {Soil }}+\Delta S_{\text {Groundwater recharge }}\right) \quad$ (Equations 1,2$)$

Precipitation was based on climate data for each case study region from the online climate tool CliPick (Palma 2017). Evapotranspiration was calculated by the FAO Penman-Monteith equation (Allen et al. 1998) and the MODIFFUS 3.0 methodology (Hürdler et al. 2015) was applied to assess the surface runoff. The groundwater recharge rate (GWRR) involves the amount of rainfall that percolates into the groundwater (Equation 3).

$G W R R=\frac{\Delta S_{\text {Groundwater recharge }}}{P} * 100$

(Equation 3)

In particular, DEM and soil information obtained from Panagos et al. (2012); Hiederer (2013); Ballabio et al. (2016); Makó et al. (2017) were used.

The assessment of nitrate leaching was based on the water cycle modelling and by deploying the MODIFFUS 3.0 method (Hürdler et al. 2015), an empirical model for nitrate and phosphorus losses. Herein leaching values for each land cover class weighted by factors for soil characteristics, fertilizer application, and drainage were set.

The RUSLE equation (Renard et al. 1997) was applied to assess soil loss by water. Herein the rainfall-runoff erosivity factor $(\mathrm{R})$ is multiplied by the soil erodibility factor $(\mathrm{K})$, the slope length factor $(\mathrm{L})$, the slope steepness factor $(\mathrm{S})$, the cover management factor $(\mathrm{C})$ and the support practice factor $(\mathrm{P})$. These results in the average soil loss (A) (Equation 4).

$A=R * K * L * S * C * P$

(Equation 4)

The spatial data were provided from the European Soil Database (ESDB) (in particular Panagos et al., 2014, Panagos et al., 2015, Panagos et al., 2016). 
Carbon sequestration was estimated as the sum of above and below ground crop and tree biomass, based on EcoYield-SAFE and in addition the soil organic carbon (SOC), modelled in YASSO0.7 (Liski et al. 2005). The YASSO model was primarily developed for forest stands, focusing on the decomposition of biomass fractions and their effects on soil carbon. The carbon assessment was divided into annual sequestration rate and total carbon stock.

The biodiversity assessment was divided into functions and capacities of nature represented by pollination and habitat richness and diversity. Lonsdorf et al. (2009) equations were spatially applied for evaluating the pollination potential for cavity and ground nesting species for 100 and $350 \mathrm{~m}$ flight and foraging distances. As a pre-requisite, flowering and nesting facilities for wild pollinators were recorded during the habitat mapping (except for the UK case study region). Landscape metrics, computed from the habitat maps of the LTS, were used as proxies for habitat richness (Billeter et al. 2008), particularly the Simpson diversity index (SIDI), the share of semi-natural habitat (SoSNH) and the number of semi-natural habitat types (HD).

The analysis of ES was conducted on two spatial levels. Firstly, the analysis was done at regional level comparing agroforestry and non-agroforestry LTS of each case study region separately. Secondly the results were aggregated at a landscape level including all LTS. All results were statically tested using t-tests and linear regressions in $\mathrm{R}$ ( $\mathrm{R}$ Development Core Team 2013). The spatial analysis was performed in ArcGIS10.4 (ESRI 2016) and SAGA GIS (Conrad et al. 2015). The methods were described in detail by Kay et al. (submitted).

\section{Results}

Examples of the LTS habitat maps are shown in Figure 2. The range of results, separately per ES indicator, obtained from the model are summarised in Figure 3. Herein the spatially explicit results are aggregated to case study level, divided into agroforestry (AF) and non-agroforestry (NAF) LTS and arranged into Mediterranean, Continental and Atlantic regions. The analysis was done (i) for each case study and (ii) aggregated across all case study regions. 


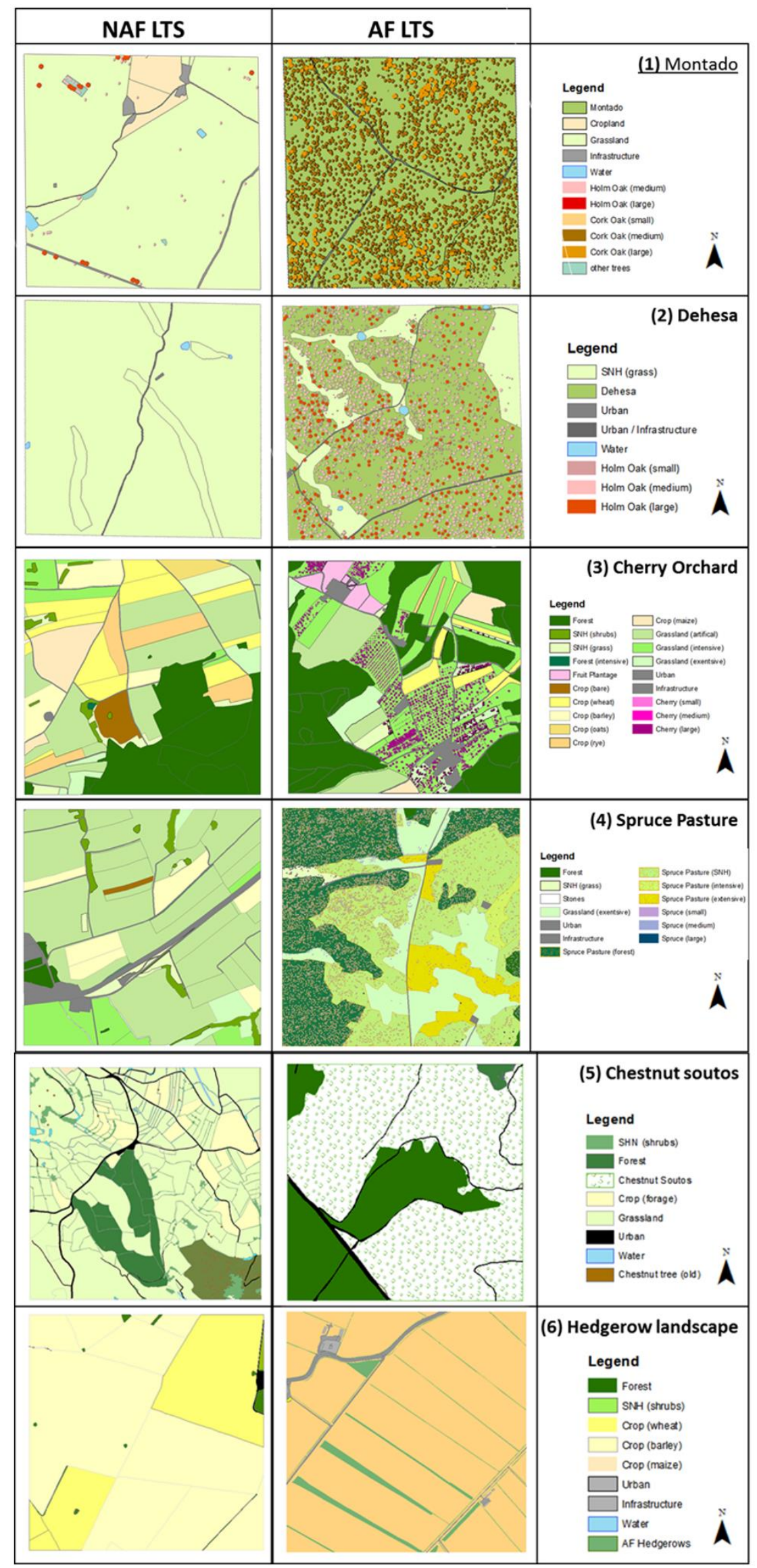

Figure 2: Examples of habitat maps of an agroforestry $(A F)$ and a non-agroforestry (NAF) landscape test site (LTS) for each case study region. 


\subsection{Biomass}

The annual use of biomass, mainly the crop yield plus tree prunings, ranged from 1.7 up to 14.5 $\mathrm{t} \mathrm{ha}^{-1} \mathrm{yr}^{-1}$ with an average of $4.3 \mathrm{t} \mathrm{ha}^{-1} \mathrm{yr}^{-1}$. In most regions, agricultural NAF LTS showed higher annual yields than AF landscapes. Exceptions were the Mediterranean systems, where the agroforestry LTS produced higher yields. Statistically validated differences between NAF and AF plots were found for montado, cherry orchards and spruce pasture (Table2 and Figure 3). Over all regions, the variation between AF and NAF LTS was not statistically significant. For the total stock value at any one time $\left(\mathrm{t} \mathrm{DM} \mathrm{ha}^{-1}\right)$, which represents mainly the total volumen of timber, the trends were reversed. With $25 \mathrm{t} \mathrm{ha}^{-1}$, AF landscapes had higher average biomass stocks than NAF $\left(15.6 \mathrm{t} \mathrm{ha}^{-1}\right)$. The outcomes varied between $0.1 \mathrm{t} \mathrm{ha}^{-1}$ to $72 \mathrm{tha}^{-1}$. The overall comparison showed no significant difference between AF and NAF, while in montado, dehesa and spruce pasture significant variations were found. 


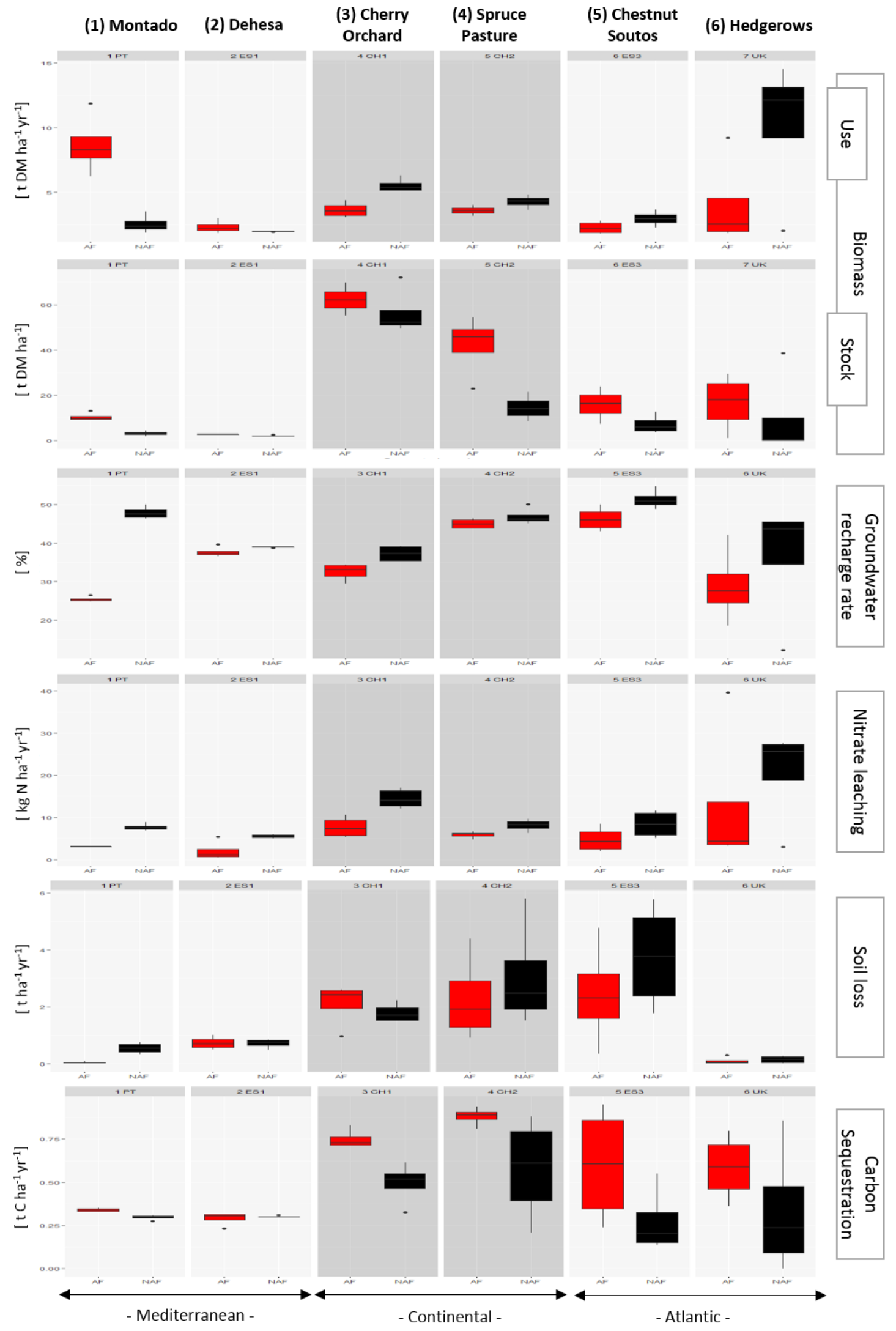




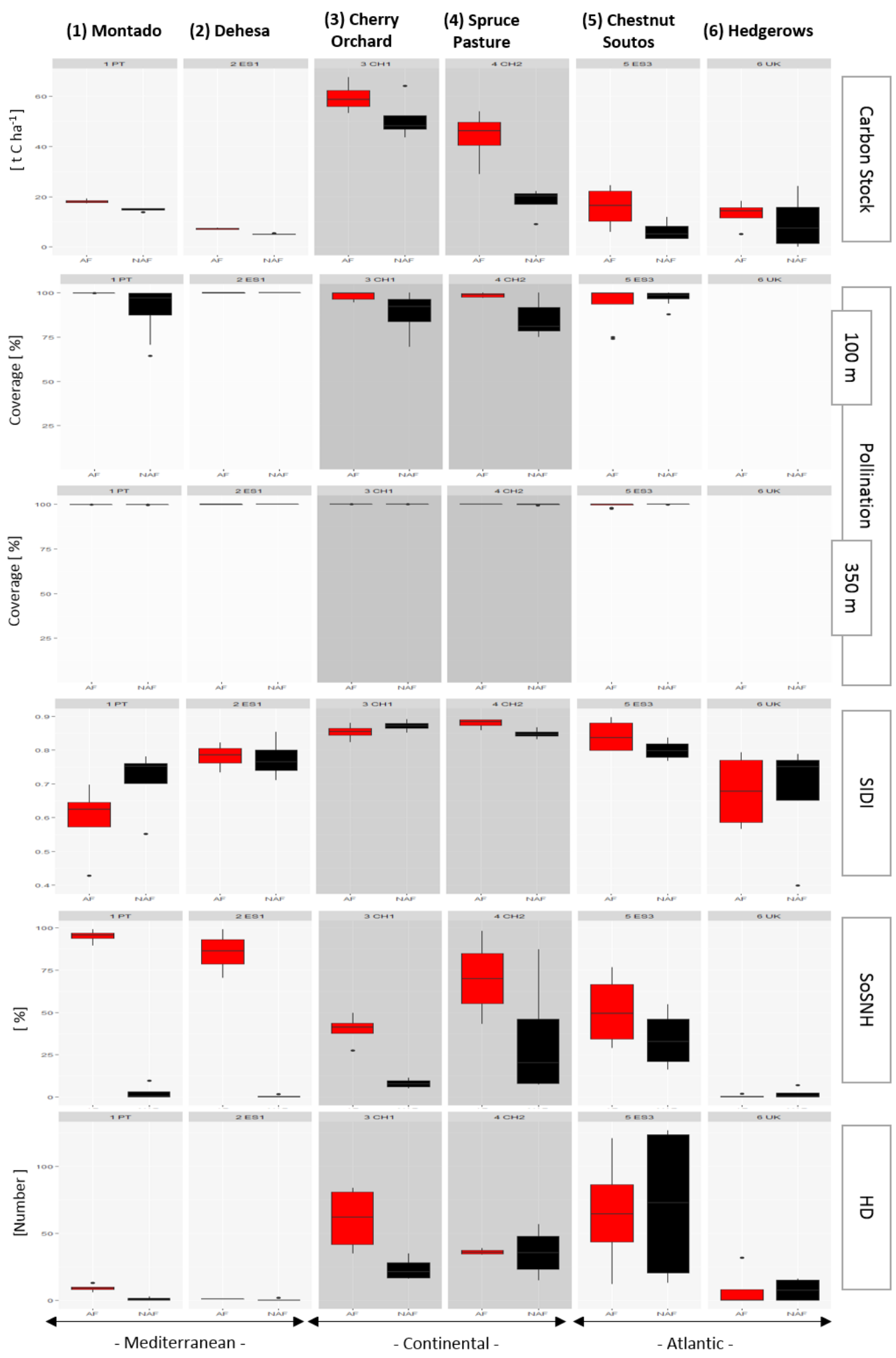

Figure 3: Summary of ES assessment grouped into agroforestry (AF - red) and non-agroforestry (NAF - black) landscape test sites for each case study region clustered into Mediterranean, Continental and Atlantic regions. Pollination services could not be evaluated for the UK. The bar graphs indicate mean values (horizontal line), standard deviation (upper and lower limits of boxes), range of values (lines) and outliers (points) [SIDI: Simpson's diversity index, SoSNH: share of semi-natural habitat, HD: Habitat Diversity] 


\subsection{Groundwater recharge}

The groundwater recharge rate varied between 18 and $54 \%$ of the annual precipitation. The lowest values were obtained in agroforestry landscapes in the United Kingdom, while the highest values were in non-agroforestry LTS in Galicia and Portugal. The evapotranspiration was always higher in agroforestry areas. The recharge rate in AF LTS ranged between $28.7 \%$ and $46.4 \%$ with an average of $36.9 \%$. In NAF LTS the range was higher: between $35.3 \%$ to $54.9 \%$, with an average of $43.6 \%$. These differences were statistically significant across all regions $(\mathrm{p}<0.01)$.

\subsection{Nitrate leaching}

Values for nitrate leaching were very low, especially in southern Europe. They ranged between nearly 0 up to $37 \mathrm{~kg} \mathrm{~N} \mathrm{ha}^{-1} \mathrm{yr}^{-1}$. AF LTS tended to leach less nitrate than NAF LTS; in average $5.2 \mathrm{~kg} \mathrm{~N} \mathrm{ha}^{-1} \mathrm{yr}^{-1}$ in AF as compared to $9.9 \mathrm{~kg} \mathrm{~N} \mathrm{ha}^{-1} \mathrm{yr}^{-1}$ in NAF. These overall differences between land cover classes were significant $(\mathrm{p}<0.05)$. Within the regions, cherry orchards and spruce pasture in Switzerland, dehesa and montado showed statistically verifiable variations between agroforestry and non-agroforestry test sites (Table2).

\subsection{Soil loss}

The indicator of soil loss showed strong variations within and across regions. The average loss was $1.39 \mathrm{t} \mathrm{ha}^{-1} \mathrm{yr}^{-1}$ in $\mathrm{AF}$, covering a range of 0.01 to $4.7 \mathrm{tha}^{-1} \mathrm{yr}^{-1}$, and $1.59 \mathrm{t} \mathrm{ha}^{-1} \mathrm{yr}^{-1}$ in NAF (0.04 - $\left.5.80 \mathrm{tha}^{-1} \mathrm{yr}^{-1}\right)$. No significant differences were found among AF and NAF LTS across all regions and within case study regions. Because soil loss and topography are closely interlinked, we tested soil loss against slope. Standard multiple linear regression models were used to relate AF and NAF LTS (Figure 4), p-values for slope were statistically significant (p $<0.01)$ and showed a reducing effect of AF on soil loss.

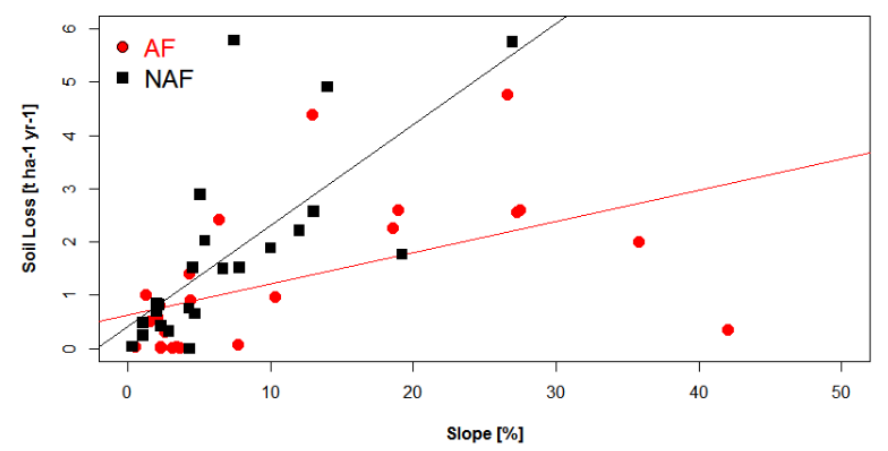

Figure 4: Erosion assessment grouped into agroforestry $(A F, r e d)$ and non-agroforestry (NAF, black) landscape test sites as a function of the slope. [p-value: 1.395e-05, Adjusted R2: 0.394] 


\subsection{Carbon sequestration}

The carbon assessment was divided into an annual carbon sequestration rate and the total carbon stock. The model results varied strongly within and across case study regions. In the overall trend agroforestry landscapes sequestered on average $0.57 \mathrm{t} \mathrm{C} \mathrm{ha}^{-1} \mathrm{yr}^{-1}$, while in NAF the value was around $0.37 \mathrm{t} \mathrm{C} \mathrm{ha}^{-1} \mathrm{yr}^{-1}(\mathrm{p}<0.01)$. The lowest average $\mathrm{C}$ sequestration rate was in cropland dominated landscapes in the UK and the highest in an agroforestry LTS in Switzerland. Results showing significant differences were found in the montado and the cherry orchards.

The model outcomes for carbon stock were similar to the carbon sequestration rate: in all case study regions, the agroforestry landscapes had a higher average amount of carbon stock compared to NAF LTS (26.2 versus $17.1 \mathrm{t} \mathrm{C} \mathrm{ha}^{-1}$ ). However, there was no overall significant difference between agroforestry and non-agroforestry areas. Significant variation was found in montado, dehesas and spruce pasture.

\subsection{Pollination}

The model demonstrated that pollinators and their services could potentially cover the whole area of most LTS within a distance of $350 \mathrm{~m}$ around the nesting facilities. The only exceptions were two NAF LTS in UK, where no flowering and nesting facilities for pollinators were mapped. Significant differences were found between all AF and NAF LTS for $100 \mathrm{~m}$ foraging distances. For the case study regions, significant effects were found for $100 \mathrm{~m}$ foraging radius in montado, cherry orchards, spruce pasture and hedgerow landscapes.

\subsection{Habitat Richness}

The Simpson's diversity index assessment ranged between 0.3 and 0.89 . The highest levels of diversity were recorded in the Swiss case study regions, while the lowest values were observed in a non-agroforestry LTS in the UK. None of the differences were statistically significant, though.

The variability of SoSNH was huge, with an overall trend towards a higher share of semi-natural habitats in agroforestry landscapes $(\mathrm{p}<0.001)$. In particular, this difference was statistically significant in the montado, dehesa and cherry orchard case study regions.

The indicator Total HD was also derived from mapping and showed wide-ranging values between 10 to more than 100 semi-natural habitat types per LTS. Although no correlation could be found across all case study regions, significant differences between the categories AF and NAF were revealed in the montado and the cherry orchard landscapes. 
Table 2: Summary of statistically significant differences (p-values as a result of independent 2-group t-test) between agroforestry $(A F)$ and non-agroforestry (NAF) landscape test sites (LTS) for all Ecosystem Service indicators in each case study and across all case study sites [PT: Montado Portugal, ES1: Dehesa Spain, CH1: Cherry Orchards Switzerland, CH2: Spruce pasture Switzerland, ES2: Chestnut soutos, Spain, UK: Hedgerow agroforestry United Kingdom; *: p<0.05, **: $p<0.01$, ***: $p<0.001$, NA: Pollination services could not be evaluated for the UK; $(A F)$ : AF LTS values higher, $(N A F)$ : NAF LTS values higher ]

\begin{tabular}{|c|c|c|c|c|c|c|c|c|}
\hline \multicolumn{2}{|c|}{ Ecosystem Service Indicators } & \multicolumn{6}{|c|}{ Case study regions } & \multirow{2}{*}{$\begin{array}{l}\text { All case } \\
\text { study } \\
\text { regions }\end{array}$} \\
\hline & & PT & ES1 & CH1 & CH2 & ES2 & UK & \\
\hline \multirow[t]{2}{*}{ Biomass } & Use & $* *(\mathrm{AF})$ & & $* *(\mathrm{NAF})$ & & & & \\
\hline & Stock & $* *(\mathrm{AF})$ & $*(\mathrm{AF})$ & & $*(\mathrm{AF})$ & & & \\
\hline Water & Recharge Rate & $* * *$ (NAF) & & $*(\mathrm{NAF})$ & & $*(\mathrm{NAF})$ & & $* *(\mathrm{NAF})$ \\
\hline \multicolumn{2}{|c|}{ Nutrient retention } & $* *(\mathrm{NAF})$ & & $* *(\mathrm{NAF})$ & $*(\mathrm{NAF})$ & & & $*(\mathrm{NAF})$ \\
\hline \multicolumn{2}{|c|}{ Soil conservation } & $*(\mathrm{NAF})$ & & & & & & \\
\hline \multirow[t]{2}{*}{ Carbon } & Sequestration & $* *(\mathrm{AF})$ & & $*(\mathrm{AF})$ & & & & $* *(\mathrm{AF})$ \\
\hline & Stock & $* *(\mathrm{AF})$ & $* * *(\mathrm{AF})$ & & $* *(\mathrm{AF})$ & & & \\
\hline \multirow[t]{4}{*}{ Pollination } & $100 m$ cavity & & & & $*(\mathrm{AF})$ & & NA & \\
\hline & $100 \mathrm{~m}$ ground & & & & & & NA & \\
\hline & $350 \mathrm{~m}$ cavity & & & & & & $\mathrm{NA}$ & \\
\hline & $350 \mathrm{~m}$ ground & & & & & & NA & \\
\hline \multicolumn{2}{|c|}{$\begin{array}{l}\text { Simpson's diversity index } \\
\text { (SIDI) }\end{array}$} & & & & $*(\mathrm{AF})$ & & & \\
\hline \multicolumn{2}{|c|}{$\begin{array}{l}\text { Share of semi-natural habitat } \\
\text { (SoSNH) }\end{array}$} & $* * *(\mathrm{AF})$ & $* * *(\mathrm{AF})$ & $* *(\mathrm{AF})$ & & & & $* * *(\mathrm{AF})$ \\
\hline \multicolumn{2}{|c|}{ Habitat Diversity (HD) } & $* *(\mathrm{AF})$ & & & & & & \\
\hline
\end{tabular}

\section{Discussion}

The results demonstrate a positive impact of agroforestry practices and systems on the supply of regulating ES at the landscape scale for all compared agroforestry systems regardless of type, region or composition. This is all the more remarkable as the agroforestry area is between $5 \%$ in the hedgerow landscapes in the UK, where only the hedgerows are qualified as AF and around $95 \%$ in dehesas, Spain (Figure 1). Also, most LTS included all habitat types present in the respective region, i.e. also NAF landscapes contained some agroforestry plots - although at a much lower percentage than the AF LTS. Thus, differences between ES indicator values at LTS scale are less striking than they would have been at plot scale. However, plot scale comparisons are misleading for ES that involve processes that interact spatially (e.g. erosion, pollination). Nonetheless the positive effect on regulating ES provision is directly interlinked with the amount of agroforestry in the LTS.

Nitrogen leaching mainly occurs during autumn and winter season, when the nutrient uptake of plants is limited, but also during spring caused by intensive rainfall. Approaches for reducing theses effects like using crops with higher water requirements, optimized fertilization and a 
permanent, year-round land cover optimally with trees were positively examined by for example Joffre et al. (1999), Herzog et al. (2008) and López-Díaz et al. (2011). In line with those observations, considering the tree as a permanent crop, nitrate leaching in the AF LTS was systematically lower than in the NAF LTS.

García-Ruiz et al. (2015) compared erosion rates in a meta-analysis. Slope and precipitation had the highest effect on soil loss, immediately followed by land use. Our AF LTS tended to have overall higher slope percentages. As a result, there was no significant difference between AF and NAF LTS, except for the orchards, where soil loss was actually higher in the agroforestry landscapes because orchards were systematically present on steeper slopes than the non-agroforestry land uses. Only in the montado LTS, erosion was significantly reduced on AF LTS.

Due to high biomass stock and lower decomposability of tree leaves and roots (Cornwell et al. 2008), AF LTS showed higher carbon sequestration rates and higher landscape carbon stock compared to agricultural LTS. The overall high carbon storage is particularly high in the Swiss case study regions. This is mainly due to the heterogeneous landscape structure and the amount of productive forest areas in the LTS. Yet, a recent investigation in an apple intercropping system showed increased carbon soil contents already seven years after tree planting (Seitz et al. 2017). The carbon sequestration rate in spruce wooded pasture is remarkably high, following the high productivity of coniferous tree species (Bebi et al. 2013). Chestnut soutos in Atlantic climates showed slightly lower values, hence the variance was higher within the region. Interestingly, small variations were found in dehesa in comparison to montado. This may be a result of the lower tree density in dehesa and edaphoclimatic conditions, changing storage in trees that can have wide difference in carbon storage (Palma et al. 2014). Howlett et al. (2011) measured an additional soil carbon storage in oak dominated agroforestry systems of around $4 \%$ in comparison to pasture without trees.

Zulian et al. (2013) examined pollination services at European scale. In natural reserves and areas with semi-natural habitats, the full service was determined. Agroforestry systems were qualified as semi-natural habitats and provide a high level of pollination services. Only little differences were found between AF and NAF LTS within the case study regions, mainly due to geographical proximity between the LTS and the overall complexity of the examined landscapes. Agri-environmental schemes have in general a positive impact on pollinator species richness and abundance, hence, these effects are even more strongly related to the structure and complexity of the broader landscape context (Scheper et al. 2013) . 
Biodiversity needs to be evaluated at the landscape rather than at the plot scale, due to the importance of spatial interactions between habitats and species (e.g.Tscharntke et al. 2005). For the biodiversity metrics use here, differences were larger between case study regions than between AF and NAF LTS. This indicates the influence and relevance of broad landscapes contexts $\left(>1 \mathrm{~km}^{2}\right.$ ) in biodiversity assessments. In several case study regions, habitat diversity (SIDI) was lower in AF LTS than in NAF LTS. This is due to, for example, the lower diversity of crops in the cherry orchard landscapes and uniformally mapped AF in montados. The share of semi-natural habitats (SoSNH), on the other hand, was consistently higher in AF LTS than in NAF LTS because agroforestry systems were classified as semi-natural, in line with the European Habitats Directive (European Commission 1992) and the European High-Nature Value categories (Oppermann et al. 2012). In the UK hedgerow landscape, however, only the area of the hedgerows were classified as $\mathrm{SNH}$, which leads in total to a low SNH coverage. Comparatively fewer habitats types (HD) in montado and dehesa are again a result of their large and homogenous spatial extent (Gaspar et al. 2007) and therefore uniform mapping of these systems. Nevertheless, marginal-unmanaged habitats, even if they only occur occasionally, are crucial for biodiversity in Iberian dehesas (Moreno et al. 2016).

Regarding provisioning ES, the results were more heterogeneous. The annual biomass use tended to be higher in NAF than in AF LTS except for montado. In this case the comparable agricultural practice was permanent grassland and in the Mediterranean climate, the presence of woody vegetation actually increases the forage availability by reducing wind speed and the water deficit in some periods of the year (Moreno and Cubera 2008; Pardini 2009), in addition to the acorns that also provide forage. Yield differences between the montado and dehesa case study regions could be explained by different agro-climatic conditions and tree density in the case studies (montado 50 vs. dehesa 20 trees ha-1). In contrast, the biomass stock tended to be higher in AF LTS as compared to NAF LTS. This is due to the long-term biomass stored in trees. The high values in the Swiss case study regions are related to the biomass rich forest, which are part of the LTS. Variable climate conditions account for differences between the NAF landscapes in the two Swiss case study regions. While in the orchard region the focus is on cereal production, the mountain area produces mainly grass and fodder for animals. For groundwater recharge - the other provisioning ES that was evaluated, the findings were again consistent across case study regions and agroforestry systems. Vegetation cover strongly affects groundwater recharge (Campos et al. 2013) and evapotranspiration is usually higher when trees are present, due to the higher biomass stock and the increased interception of rainfall (e.g. Bellot et al. 1999; Grubinger 2015). Consequently, groundwater recharge tended to be lower in the 
agroforestry landscapes across all LTS. The highest values occurred in regions with high precipitation rates, like in the chestnut soutos or the spruce pasture.

\section{Conclusion}

The spatially-explicit link between ecosystem service provision and landscape structure enables a general assessment of the contribrution of agroforestry to landscape enhancement. The multifunctionality of agroforestry systems in comparison to agricultural landscapes was reflected by reduced nitrate losses, higher carbon sequestration, reduced soil loss, higher pollination services and higher porportions of semi-natural habitats. Higher annual yields and higher groundwater recharge rates were linked to NAF areas. Whilst in traditional agroforestry landscapes the provisioning ecosystem services were lower and less biomass was leaving the system per hectare and year (with exception of Mediterranean agroforestry systems), regulating ES tended to perform better in AF landscapes.

Overall our study underlines that traditional agroforestry systems regardless of type, region and composition have a beneficial impact on the provision of regulating ecosystem services at the landscape scale. These general findings encourage to expect comparable results also for innovative agroforestry systems such as alley cropping or intercropping and grazed orchards. Against this background agroforestry systems can make a significant contribution to foster European environment policy and promote sustainable agriculture.

\section{Acknowledgements}

We acknowledge funding through Grant 613520 from the European Commission (Project AGFORWARD, 7th Framework Program), the Xunta de Galicia, Consellería de Cultura, Educación e Ordenación Universitaria ("Programa de axudas á etapa posdoutoral DOG n¹22, 29/06/2016 p.27443, exp: ED481B 2016/071-0”), the Forest Research Center strategic project (PEst OE/AGR/UI0239/2014) and the Portuguese Foundation for Science and Technology through the contract SFRH/BD/52691/2014. We are grateful for the helpful comments provided by three anonymous reviewers on previous versions of this manuscript. 


\section{Literature}

AFN (2010) Inventário Florestal Nacional Portugal Continental IFN5, 2005 - 2006. Lisboa

Allen RG, Pereira LS, Raes D, et al (1998) Crop evapotranspiration-Guidelines for computing crop water requirements-FAO Irrigation and drainage paper 56.

Bailey D, Billeter R, Aviron S, et al (2007) The influence of thematic resolution on metric selection for biodiversity monitoring in agricultural landscapes. Landsc Ecol 22:461-473. doi: 10.1007/s10980-006-9035-9

Bailey D, Schmidt-Entling MH, Eberhart P, et al (2010) Effects of habitat amount and isolation on biodiversity in fragmented traditional orchards. J Appl Ecol 47:1003-1013. doi: 10.1111/j.1365-2664.2010.01858.x

Ballabio C, Panagos P, Monatanarella L (2016) Mapping topsoil physical properties at European scale using the LUCAS database. Geoderma 261:110-123. doi: 10.1016/j.geoderma.2015.07.006

Bebi P, Krumm F, Brändli UB, Zingg A (2013) Dynamik dichter, gleichförmiger Gebirgsfichtenwälder. Schweizerische Zeitschrift fur Forstwes 164:37-46. doi: 10.3188/szf.2013.0037

Bellot J, Sánchez JR, Chirino E, et al (1999) Effect of different vegetation type cover on the soil water balance in semi-arid areas of South Eastern Spain. Phys Chem Earth 24:353-357. doi: 10.1016/S1464-1909(99)000131

Biasi R, Brunori E, Ferrara C, Salvati L (2016) Towards sustainable rural landscapes? a multivariate analysis of the structure of traditional tree cropping systems along a human pressure gradient in a mediterranean region. Agrofor Syst 1-19. doi: 10.1007/s10457-016-0006-0

Billeter R, Liira J, Bailey D, et al (2008) Indicators for biodiversity in agricultural landscapes: A pan-European study. J Appl Ecol 45:141-150. doi: 10.1111/j.1365-2664.2007.01393.x

Buttler A, Kohler F, Gillet F, Nair PKR (2009) The Swiss Mountain Wooded Pastures: Patterns and Processes. Agrofor Eur Curr Status Futur Prospect 6:377-396. doi: 10.1007/978-1-4020-8272-6_19

Campos I, Villodre J, Carrara A, Calera A (2013) Remote sensing-based soil water balance to estimate Mediterranean holm oak savanna (dehesa) evapotranspiration under water stress conditions. J Hydrol 494:19. doi: 10.1016/j.jhydrol.2013.04.033

Conrad O, Bechtel B, Bock M, et al (2015) System for Automated Geoscientific Analyses (SAGA) v. 2.1.4. Geosci Model Dev 8:1991-2007. doi: 10.5194/gmd-8-1991-2015

Cornwell WK, Cornelissen JHC, Amatangelo K, et al (2008) Plant species traits are the predominant control on litter decomposition rates within biomes worldwide. Ecol Lett 11:1065-1071. doi: 10.1111/j.14610248.2008.01219.x

Dale VH, Polasky S (2007) Measures of the effects of agricultural practices on ecosystem services. Ecol Econ 64:286-296. doi: 10.1016/j.ecolecon.2007.05.009

den Herder M, Moreno G, Mosquera-Losada RM, et al (2017) Current extent and stratification of agroforestry in the European Union. Agric Ecosyst Environ 241:121-132. doi: 10.1016/j.agee.2017.03.005

ESRI (Environmental Systems Resource Institute) (2016) ArcGIS Desktop: Release 10.4. Redlands CA

European Commission (1992) Council Directive 92/43/EEC of 21 May 1992 on the conservation of natural habitats and of wild fauna and flora. Council of the European Communities (CEC). Off J Eur Communities 206:7-50.

Eurostat (2013) Land cover statistics.

Fagerholm N, Oteros-Rozas E, Raymond CM, et al (2016) Assessing linkages between ecosystem services, landuse and well-being in an agroforestry landscape using public participation GIS. Appl Geogr 74:30-46. doi: 10.1016/j.apgeog. 2016.06 .007

FAO (2017) FAO Statistic - CROPS

García-Ruiz JM, Beguería S, Nadal-Romero E, et al (2015) A meta-analysis of soil erosion rates across the world. Geomorphology 239:160-173.

Gaspar P, Mesías FJ, Escribano M, et al (2007) Economic and management characterization of dehesa farms: Implications for their sustainability. Agrofor Syst 71:151-162. doi: 10.1007/s10457-007-9081-6

Grubinger H (2015) Basiswissen Kulturbautechnik und Landneuordnung - Planung, Bewertung, Nutzung und Schutz unserer Lebensräume für Planer, Kulturbau- und Umweltingenieure. Schweizerbart'sche Verlagsbuchhandlung

Haines-Young R, Potschin M (2013) Common International Classification of Ecosystem Services (CICES): Consultation on Version 4, August-December 2012.

Herzog F (1998a) Streuobst: A traditional agroforestry system as a model for agroforestry development in temperate Europe. Agrofor Syst 42:61-80. doi: 10.1023/A:1006152127824

Herzog F (1998b) Agroforestry in temperate Europe: history, present importance and future development. Keulen H van, Lantinga EA van Laar HH Mix Farming Syst Eur 47-52.

Herzog F, Prasuhn V, Spiess E, Richner W (2008) Environmental cross-compliance mitigates nitrogen and phosphorus pollution from Swiss agriculture. Environ Sci Policy 11:655-668. doi: 10.1016/j.envsci.2008.06.003

Hiederer R (2013) Mapping Soil Properties for Europe - Spatial Representation of Soil Database Attributes. 
Howlett DS, Mosquera-Losada MR, Nair PKR, et al (2011) Soil carbon storage in silvopastoral systems and a treeless pasture in northwestern Spain. J Environ Qual 40:825-832. doi: 10.2134/jeq2010.0145

Hürdler J, Prasuhn V, Spiess E (2015) Abschätzung diffuser Stickstoff- und Phosphoreinträge in die Gewässer der Schweiz.

Jarvis A, Reuter HII, Nelson A, Guevara E (2008) Hole-filled seamless SRTM data V4. Int. Cent. Trop. Agric. available from http://srtm.csi.cgiar.org.

Joffre R, Rambal S, Ratte JP (1999) The dehesa system of southern Spain and Portugal as a natural ecosystem mimic. Agrofor Syst 45:57-79. doi: 10.1007/978-3-642-15720-2_16

Jose S (2009) Agroforestry for ecosystem services and environmental benefits: An overview. Agrofor Syst 76:110. doi: 10.1007/s10457-009-9229-7

Kay S, Crous-Duran J, Garcia de Jalon S, et al Landscape-scale modelling of agroforestry ecosystems services: A methodological approach. submitted

Liski J, Palosuo T, Peltoniemi M, Sievänen R (2005) Carbon and decomposition model Yasso for forest soils. Ecol Modell 189:168-182. doi: 10.1016/j.ecolmodel.2005.03.005

Lonsdorf E, Kremen C, Ricketts T, et al (2009) Modelling pollination services across agricultural landscapes. Ann Bot 103:1589-1600. doi: 10.1093/aob/mcp069

López-Díaz ML, Rolo V, Moreno G (2011) Trees' role in nitrogen leaching after organic, mineral fertilization: a greenhouse experiment. J Environ Qual 40:853-9. doi: 10.2134/jeq2010.0165

Maes J, Egoh B, Willemen L, et al (2012) Mapping ecosystem services for policy support and decision making in the European Union. Ecosyst Serv 1:31-39. doi: 10.1016/j.ecoser.2012.06.004

Makó A, Kocsis M, Barna G, Tóth G (2017) Mapping the storing and filtering capacity of European soils.

McNeely JA, Schroth G (2006) Agroforestry and biodiversity conservation - traditional practices, present dynamics, and lessons for the future. Biodivers Conserv 15:549-554. doi: 10.1007/s 10531-005-2087-3

MEA (2003) Ecosystems and human well-being. Washington, DC: Island Press

Moreno G, Cubera E (2008) Impact of stand density on water status and leaf gas exchange in Quercus ilex. For Ecol Manage 254:74-84. doi: 10.1016/j.foreco.2007.07.029

Moreno G, Gonzalez-Bornay G, Pulido F, et al (2016) Exploring the causes of high biodiversity of Iberian dehesas: the importance of wood pastures and marginal habitats. Agrofor Syst 90:87-105. doi: 10.1007/s10457-0159817-7

Mouchet MA, Paracchini ML, Schulp CJE, et al (2017) Bundles of ecosystem (dis)services and multifunctionality across European landscapes. Ecol Indic 73:23-28. doi: http://dx.doi.org/10.1016/j.ecolind.2016.09.026

Nati C, Montorselli NB, Olmi R (2016) Wood biomass recovery from chestnut orchards: results from a case study. Agrofor Syst 1-15. doi: 10.1007/s10457-016-0050-9

Oppermann R, Beaufoy G, Jones G (2012) High nature value farming in Europe. verlag regionalkultur UbstadtWeiher

Palma J, Graves A, Crous-Duran J, et al EcoYield-SAFE: maintaining a parameter-sparse approach in modelling silvopastoral systems. submitted

Palma JHN (2017) Clipick - climate change web picker. A tool bridging daily climate needs in process based modelling in forestry and agriculture. For Syst. doi: 10.5424/fs/2017261-10251

Palma JHN, Paulo JA, Tomé M (2014) Carbon sequestration of modern Quercus suber L. silvoarable agroforestry systems in Portugal: A yieldSAFE-based estimation. Agrofor Syst 88:791-801. doi: 10.1007/s10457-0149725-2

Panagos P, Ballabio C, Borrelli P, Meusburger K (2016) Spatio-temporal analysis of rainfall erosivity and erosivity density in Greece. Catena 137:161-172. doi: 10.1016/j.catena.2015.09.015

Panagos P, Borrelli P, Meusburger K, et al (2015a) Estimating the soil erosion cover-management factor at the European scale. Land use policy 48:38-50. doi: 10.1016/j.landusepol.2015.05.021

Panagos P, Borrelli P, Poesen J, et al (2015b) The new assessment of soil loss by water erosion in Europe. Environ Sci Policy 54:438-447. doi: 10.1016/j.envsci.2015.08.012

Panagos P, Meusburger K, Ballabio C, et al (2014) Soil erodibility in Europe: A high-resolution dataset based on LUCAS. Sci Total Environ 479-480:189-200. doi: 10.1016/j.scitotenv.2014.02.010

Panagos P, Van Liedekerke M, Jones A, Montanarella L (2012) European Soil Data Centre: Response to European policy support and public data requirements. Land use policy 29:329-338. doi: 10.1016/j.landusepol.2011.07.003

Pardini A (2009) Agroforestry systems in Italy: traditions towards modern management. In: Agroforestry in Europe. Springer, pp 255-267

Pereira H, Tomé M (2004) Cork oak. Encyclopedia of forest sciences. Elsevier, Oxford 613-620.

Pimentel D, Stachow U, Takacs D a, et al (1992) Conserving Biological Diversity in Most biological diversity exists in human-managed ecosystems Agricultural / F Systems. Most 42:354-362. doi: 10.2307/1311782

Plieninger T, Hartel T, Martín-López B, et al (2015) Wood-pastures of Europe: Geographic coverage, socialecological values, conservation management, and policy implications. Biol Conserv 190:70-79. doi: 10.1016/j.biocon.2015.05.014 
Renard K, Foster G, Weesies G, et al (1997) Predicting soil erosion by water: a guide to conservation planning with the Revised Universal Soil Loss Equation (RUSLE).

Reuter HI, Nelson A, Jarvis A (2007) An evaluation of void-filling interpolation methods for SRTM data. Int J Geogr Inf Sci 21:983-1008. doi: 10.1080/13658810601169899

Rigueiro-Rodríguez A, Santiago-Freijanes JJ, Ferreiro-Dominguez N, et al (2014) Celtic pig production in chestnut extensive systems in Galicia. In: 2 nd EURAF Conference. EURAF,

Scheper J, Holzschuh A, Kuussaari M, et al (2013) Environmental factors driving the effectiveness of European agri-environmental measures in mitigating pollinator loss - a meta-analysis. Ecol Lett 16:912-920. doi: 10.1111/ele. 12128

Seitz B, Carrand E, Burgos S, et al (2017) Erhöhte Humusvorräte in einem siebenjährigen Agroforstsystem in der Zentralschweiz / Augmentation des stocks d'humus dans un systeme agroforestier de sept ans en Suisse centrale. Agrar Schweiz 8:318-323.

Tilman D (1999) Global environmental impacts of agricultural expansion: the need for sustainable and efficient practices. Proc Natl Acad Sci U S A 96:5995-6000. doi: 10.1073/pnas.96.11.5995

Torralba M, Fagerholm N, Burgess PJ, et al (2016) Do European agroforestry systems enhance biodiversity and ecosystem services? A meta-analysis. Agric Ecosyst Environ 230:150-161. doi: 10.1016/j.agee.2016.06.002

Tscharntke T, Klein AM, Kruess A, et al (2005) Landscape perspectives on agricultural intensification and biodiversity - Ecosystem service management. Ecol Lett 8:857-874. doi: 10.1111/j.14610248.2005.00782.x

Turner KG, Odgaard MV, Bøcher PK, et al (2014) Bundling ecosystem services in Denmark: Trade-offs and synergies in a cultural landscape. Landsc Urban Plan 125:89-104. doi: 10.1016/j.landurbplan.2014.02.007

van der Werf W, Keesman K, Burgess P, et al (2007) Yield-SAFE: A parameter-sparse, process-based dynamic model for predicting resource capture, growth, and production in agroforestry systems. Ecol Eng 29:419433. doi: 10.1016/j.ecoleng.2006.09.017

van der Zanden EH, Levers C, Verburg PH, Kuemmerle T (2016) Representing composition, spatial structure and management intensity of European agricultural landscapes: A new typology. Landsc Urban Plan 150:36-49. doi: 10.1016/j.landurbplan.2016.02.005

Zulian G, Maes J, Paracchini M (2013) Linking Land Cover Data and Crop Yields for Mapping and Assessment of Pollination Services in Europe. Land 2:472-492. doi: 10.3390/land2030472 